\title{
InTERnATIONAL
}

\section{Journal of Human Studies}

Uluslararası İnsan Çalişmalari Dergisi

ISSN: 2636-8641

Cilt/Volume 3 Sayl/Issue 5 Yll/Year: 2020 Gönderim: 12-02-2020 - Kabul: 30-05-2020

\section{Adem ÖZDEMİR ${ }^{1}$ Ahmet GÜRBÜZ ${ }^{2}$}

\begin{abstract}
The aim of this study is to determine the problems experienced in university by making use of the views of academicians working at university and to bring solutions. Academics; management and organization, education, research, infrastructure and the satisfaction level of relations with stakeholders. In the study, a method for descriptive survey, which aims to reveal the current situation, was used. The research group consists of 194 academic staff working in Ağrı İbrahim Çeçen University. Academic Personnel Satisfaction Questionnaire, which was developed by Mehmet Akif Ersoy University Academic Evaluation and Quality Improvement Committee, was used to measure academic satisfaction. The survey was previously applied to the academic staff of Mehmet Akif Ersoy University and aimed to evaluate the academic-administrative services of academicians, to make long-medium-short term
\end{abstract}

\section{Akademisyenlerin Memnuniyet Düzeylerinin Belirlenmesi: Ağrı İbrahim Çeçen Üniversitesi Örneği}

Öz

$\mathrm{Bu}$ araştırmada, üniversitede çalışan akademisyenlerin yönetim ve örgütleme, eğitim, araştırma, altyap1 ve paydaşlarla ilişkilerdeki memnuniyet düzeylerinin belirlenmesi amaçlanmıştır. Akademisyenlerin görüşlerinden yararlanarak üniversitede yaşanan sorunları tespit ederek çözüm önerileri getirmek araştırmanın diğer bir amacını oluşturmaktadır. Araştırmada, mevcut durumu ortaya çıkarmay1 amaçlayan betimsel tarama (survey) yöntemi kullanılmıştır. Araştırma grubunu Ağrı İbrahim Çeçen Üniversitesinde çalışan 194 akademik personel oluşturmaktadır. Araştırmada akademisyenlerin memnuniyet düzeyini ölçmek için Mehmet Akif Ersoy Üniversitesi Akademik Değerlendirme ve Kalite Geliştirme Kurulu tarafindan geliştirilen Akademik Personel Memnuniyet Ölçeği kullanılmıştır. Ölçek akademisyenlerin; akademik-idari hizmetleri değerlendirmesi, uzun-orta-kısa dönemli

1 Adem Özdemir, Öğretim Görevlisi, Ağr1 İbrahim Çeçen Üniversitesi, Bankac1lık ve Sigortacılık Bölümü, aozdemir@agri.edu.tr, Orcid: 0000-0003-3127-6846

${ }^{2}$ Ahmet Gürbüz, Prof. Dr., Karabük Üniversitesi, İşletme Bölümü, agurbuz@karabuk.edu.tr, Orcid: 0000-0003-2287-9709 
strategic plans and to continuously improve the quality of the services it provides. The scale consists of a personal information form and five sub-dimensions to measure demographic characteristics. These sub-dimensions are management and organization, education, research, infrastructure, relations with stakeholders. Mann-Whitney U Test was used for paired comparisons and Kruskal-Wallis Variance Analysis was used for multiple comparisons. Frequency and percentage method were used for the analysis of demographic data. As a result of the research, it was seen that the sub-dimension with the most positive opinions of the participants was the infrastructure $(\bar{x}=$ 3.47), while the sub-dimension with the most negative opinions was the research $\left(\mathrm{x}^{-}=2.68\right)$. The average of the answers given by the academicians regarding the total satisfaction survey was calculated as $\left(\mathrm{x}^{-}=3.17\right)$.

Keywords: Satisfaction Level, Quality in Higher Education, University stratejik planlarını yapmas1, üniversitenin sunduğu hizmetin kalitesini sürekli geliştirmesini amaçlamıştır. Ölçekte akademisyenlerin memnuniyet düzeylerini ölçmek için yönetim ve örgütleme, eğitim, araştırma, alt yap1 ve paydaşlarla ilişkiler alt boyutları ve demografik özellikleri ölçmek için de kişisel bilgi formu kullanılmıştır. Elde edilen verilerin analizinde ikili karşılaştırmalar için Mann-Whitney U Testi ve çoklu karşılaştırmalar için Kruskal-Wallis Varyans Analizi kullanılmıştır. Demografik verilerin analizi için frekans ve yüzde yöntemi kullanılmıştır. Araştırma soncunda, katılımciların en fazla olumlu görüş ortaya koydukları alt boyutun altyap1 olduğu görülmüşken $(\bar{x}=3,47)$, en olumsuz görüss ortaya koydukları alt boyutun ise araştırma olduğu $(\bar{x}=2,68)$ olduğu görülmüştür. Akademisyenlerin memnuniyet anketinin toplamına dair verdikleri cevapların ortalaması ise $(\bar{x}=3,17)$ olarak hesaplanmıştır.

Anahtar Kelimeler: Memnuniyet Düzeyi, Yükseköğretimde Kalite, Üniversite

\section{Giriş}

Türkiye'de son yıllarda yeni kurulan üniversitelerle birlikte üniversite sayısında ciddi artış yaşanmıştır. Şüphesiz ülkemiz eğitim sistemi içerisinde üniversiteler çok önemli bir yere sahiptir. Bu bağlamda bakıldığında üniversiteler de kendi içlerinde birbirleri ile rekabet etmekte ve nitelikli öğrencileri kendi bünyelerine çekmek için her türlü stratejiyi denemektedirler. Bu stratejilerden birisi akademik camiada isim yapmıss, kendini alanında ispatlamış ve nitelikli akademik personelleri üniversite bünyelerine katmaktır. Nasıl ki üniversiteler öğrenci kazanabilmek adına gerek alt yapı, gerek eğitim hizmetleri, gerek sportif ve sosyal faaliyetleri artırıyorlarsa akademik personeli çekebilmek için onların memnun olabilecekleri ortamı oluşturmak için çaba harcamaktadırlar.

Dünyanın neresinde olursa olsun her eğitim sisteminin amacı, ülkedeki nitelikli insan gücünün sayısını artırmak ve ülke politikaları doğrultusunda vatandaşlık eğitiminin verilmesini sağlamaktır. Bu amaç doğrultusunda her bir eğitim sistemi, yetiştirmek istediği insan modelini belirleyerek, sahip olunan eğitim felsefesine ve insan gücüne göre eğitim etkinliklerinin çerçevesini tespit eder (Karagözoğlu, 2003). 
Üniversitelerin nitelik açıdan değerlendirilmesinde, öğretim süreci ve yapılan bilimsel araştırmalar göz önünde tutulmaktadır. Bu bağlamda üniversiteler değerlendirilirken; a) üniversitede öğretim elemanları, öğrenciler ve diğer yardımcı personellerden oluşan insan faktörünün b) bölümlerin, birimlerin, merkezlerin yapısal ve fonksiyonel özelliklerinin ve c) üniversitedeki öğretimin, araştırmaların ve yönetimin ayrı ayrı değerlendirilmesi bir zorunluluk olarak görülmelidir (Rebolloso ve Pozo, 2000:253).

Akademik personelin üniversitesinden memnuniyeti; üniversitenin eğitimini, araştırma geliştirme, inovasyon performansını etkilemektedir. Handy (1981)'nin de ifade ettiği üzere bu gibi kurumlar birey kültürünün yüksek olduğu, yani çalışan insan kaynağının merkezi rolde olduğu kurumlardır. Yükseköğretim programlarının başarısı, akademik personel tarafindan yapılan önemli katkılara bağlı olmaktadır (Noordin, 2009:122).

Bir bütün olarak bakıldığında yükseköğretim kurumlarının başarısı açısından akademik personelin memnuniyetinin önemi daha da artmaktadır. Benzer bir şekilde, Machado Taylor, Soares, Ferreira ve Gouveia (2011), akademik personelin memnuniyetinin, bir bütün olarak akademinin ve yükseköğretim kurumlarının nihai başarısının temel belirleyicisi olduğunu ifade etmektedir. Eyüpoğlu ve Saner (2009:687) tarafindan yapılan çalışmada da üniversitedeki olumlu iklimin, hem akademik personelin iş memnuniyetini hem de kurumun genel verimliliğini arttırdığ1 ve bunun da öğrenci başarısını olumlu yönde etkilediği belirtilmektedir. Bu nedenle, üniversitenin de faydasına olacak bir şekilde, üniversite çalışanlarının iş memnuniyetinin sürekli bir şekilde izlenmesi ve araştırılması gerekmektedir.

\section{Yeni Kurulan Üniversiteler}

Üniversiteler araştırma ve eğitim-öğretim gibi temel iki işlevlerinin yanı sıra bilgi üretmek ve bu ürettikleri bilgiyi yayamakla da sorumludurlar. Üniversitelerin bu fonksiyonlar1 yerine getirebilmeleri ve başarılı olabilmeleri ise akademik ve idari kadrolarının niteliğine, fiziki ve teknolojik alt yapılarının gerçekleşme durumuna, ekonomik kaynaklara ve yönetimsel açıdan özerkliklerine bağlıdır (Aydemir ve Erşan, 2011).

Dünyada son zamanlarda bilim, teknoloji, sosyal ve kültürel değerler, ekonomi ve siyaset gibi pek çok alanda yaşanan hızlı değişimler insanların hayata bakışlarını değiştiriken; nitelikli insan yetiştirme misyonu olan ve düşüncelerin oluşmasında etkili olan eğitim sistemlerini de etkilemektedir. Bu etkilerin çıtıtlarını eğitim dünyasının hemen hemen her alanında gördüğümüz gibi yükseköğretim sisteminde de keskin bir şekilde karşımıza çıkmaktadır. Küreselleşme tüm dünyada, giderek kamusal alandan çıkıp, daha özerk bir kamusal kimlik kazanan yükseköğretimin, mutlak bir yeniden yapılanma gerekliliğini ortaya çıkarmıştır (Acar, 2012; Altınsoy, 2011; Ted, 2011; Şenses, 2007; Ortaş, 2002; Tanrikulu, 2001).

Türkiye'deki yükseköğretim kurumlarında da yaşanan bu değişim rüzgarına göre bir takım değişiklikler yapılmaya başlamış ve özellikle 2006 yılından sonra, pek çok yeni üniversite kurulması bu değişime ayak uydurma çabalarının sonuçları olarak karşımıza çıkmaktadır. Değişimi yakalamak ve gelişimi sağlamak amacıyla kurulan bu üniversitelerin aslında en önemli kuruluş sebepleri, politik ve ekonomik sebeplerdir (Şenses,2007; Aktan, 2007; Ortaş 2004; Marginson \& Rhodes, 2002).

Tüm bu sebepler doğrultusunda; ülkemizde yükseköğretimin yurt geneline dengeli bir şekilde dağılmasını sağlamak ve yükseköğretime olan taleplere cevap vermek amaciyla 2006 yılında 16, 2007 yılında 21, 2008 yilında 15, 2009 yilında 9, 2010 yılında 17 ve 2011 yllında 11 (Günay \& Günay, 2011);

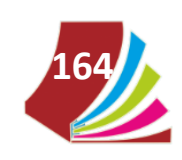


2012 yılında 3 ve 2013 yllında 1 olmak üzere toplam 93 yeni üniversite kurulmuştur. Genel olarak 2007 yılında 85 devlet ve 30 vakıf üniversitesi olmak üzere toplam 115 üniversite varken, bu say1 2020 y1lı itibariyle 129 devlet, 75 vakıf ve 5 vakıf meslek yüksek okulu olmak üzere toplamda 209'a yükselmiştir (YÖK, 2020).

Yükseköğretim sistemine bu kadar çok ve yeni üniversitenin eklenmesi bir takım sorunları da beraberinde getirmiştir. Yeni kurulan üniversitelerin coğrafik konumları, açıldıkları illerin ekonomik, sosyal ve kültürel gelişmişlikleri, öğrenci sayıları, alt yapı yetersizlikleri, öğretim elemanı sayılarının yeterli olmaması gibi sorunlarla karşı karşıya kalınmıştır.

Doğan (2013), Yeni Kurulan Üniversitelerin Sorunları ve Çözüm Önerileri başlıklı çalışmasında bu sorunları aşağıdaki gibi;

- Bürokrasi sorunlar1,

- Ekonomik sorunlar,

- Öğretim elemanı azlığı nedeniyle ders yüklerinin fazlalılı̆̆1,

- Gerek öğretim elemanlarının yabancı dil yetersizliği, gerekse de yabancı dille eğitim veren bölüm ve programların azlığ1,

- Öğretim elemanları arasında mesleki işbirliği ve dayanışmanın yetersizliği,

- Akademik yaınların niteliksiz olması ve sadece akademik unvan almak için yapılması,

- Üniversite olanaklarından yararlanmanın unvanlara göre farklılık göstermesi,

- Yeni kurulan üniversitelerde kurumsallaşma ve örgütsel yapı sorunun olması,

- Yeni kurulan üniversiteler küçük şehirlerde kurulduğundan öğretim elemanlarının çalıştıkları kurumlarla ikamet ettikleri şehirlerin farklı olması, bu durumun da öğrenci öğretim elemanı ilişkisini olumsuz yönde etkilemesi,

- Yeni kurulan üniversitelerde lisansüstü eğitim programlarının ya olmaması ya da sınırlı sayıda olmas1,

- Yeni kurulan üniversitelerde fiziki (kütüphane, laboratuvar, spor salonu vb.) ve sosyal imkanların (kafeterya, sinema, alış-veriş merkezi vb.) yetrsiz olması,

- Öğretim elemanı kadrolarının üniversitenin ihtiyacı doğrultusunda doldurulmadığından bazı bölümlerde öğretim elemanı fazlası varken bazı bölümlerde öğretim elemanı eksikliğinin olması,

- Üniversiteler arasında bir standartlaşmanın olmaması,

- Kütüphanelerin yetersiz olmas1,

s1ralamaktadir.

Araştırmaya konu olan, yukarıda sayılan sorunları yaşayan ve yeni kurulan üniversiteler arasında yer alan A ̆ğr İbrahim Çeçen Üniversitesi, 1967-1968 eğitim-öğretim yılında Milli Ĕ̆itim Bakanlığına bağlı olarak kurulan Ağrı Kız İlk Öğretmen Okulu olarak eğitim öğretim faaliyetine başlamıştır. Daha sonra ise 1977-1978 eğitim-öğretim yılında iki yıllık Ĕ̈itim Enstitüsü’ne dönüştürülerek öğretmen yetiştirme işlevini devam ettirmiştir. 30 Haziran 1982 tarihinde çıkarılan 2809 sayılı Yükseköğretim Kurumları Teşkilat Kanunu ile Ağrı Eğitim Yüksekokulu olarak Atatürk Üniversitesi Kazım Karabekir Eğitim Fakültesi’ne bağlanmıştır. 3 Temmuz 1992 tarih ve 3837 sayll kanunla Ağr1 Eğitim Yüksekokulu, Ağrı Eğitim Fakültesine dönüştürülmüş ve Atatürk Üniversitesi Rektörlügüne bağl1 olarak 2007 yllına kadar ilköğretime yönelik lisans düzeyinde eğitim ve öğretim faaliyetlerini sürdürmüştür. 17.05.2007 tarih ve 5662 sayılı kanunun Ek-73. maddesi ile Ağrı Dağ1 Üniversitesi olarak kurulan üniversitenin ismi 5773 sayılı kanunla Ağrı İbrahim Çeçen Üniversitesi olarak değiştirilmiş ve 28.06.2008 tarih ve 26920 sayılı Resmi Gazetede yayımlanarak yürürlüğe girmiştir (www.agri.edu.tr).

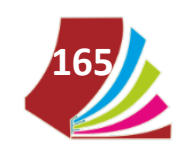


Bu bağlamda araştırmamızın temel problem cümleleri aşağıdaki sıralanabilir:

- Yeni kurulan bir üniversite olan Ağrı İbrahim Çeçen üniversitesinde görev yapan akademik personel yukarıda sayılan sorunları yaşamakta mıdır ve çalıştıkları kurumun yönetim ve örgütleme, eğitim, araştırma, altyapı ve paydaşlarla ilişkilerinden memnun mudur?

\section{Araştırmanın Tanıtılması}

\section{Arastırmanın Amac1}

Üniversitede çalışan akademisyenlerin yönetim ve örgütleme, eğitim, araştırma, altyap1 ve paydaşlarla ilişkilerdeki memnuniyet düzeylerinin belirlenmesi amaçlanmıştır. Akademisyenlerin görüşlerinden yararlanarak üniversitede yaşanan sorunları tespit ederek çözüm önerileri getirmek araştırmanın diğer bir amacını oluşturmaktadır.

\section{Araştırmanın Sinirlikklar1}

Araştırma Ağrı İbrahim Çeçen Üniversitesinde çalışan akademik personele gönüllülük esası ile yapılmıştır. Ancak araştırmanın yapıldığı esnada yerinde bulunmayan, izinli olan ya da anket formunu doldurmak istemeyen akademik personelin olması, tüm akademik personele ulaşılması engellemiştir Bu durum araştırmanın başlıca sınırlılı̆̆ıdır.

\section{Yöntem}

Araştırmada, mevcut durumu ortaya çıkarmayı amaçlayan betimsel taramaya (survey) yönelik bir yöntem kullanılmışıtır.

\section{Evren ve Örneklem}

Araştırmanın evreni Ağrı İbrahim Çeçen Üniversitesinde görev yapan akademisyenler oluşturmaktadır. Ağrı İbrahim Çeçen Üniversitesi Personel Daire Başkanlığından alınan verilere göre üniversitemizde Ekim/2019 tarihi itibariyle 450 akademik personelin çalıştığ1 tespit edilmiştir. Ancak izinli olan, araştırma yapıldığı sırada yerinde bulunmayan ve anketi cevaplamak istemeyen akademik personel olduğundan araştırmanın örneklemini araştırmaya katılan 194 akademik personel oluşturmaktadir.

\section{Veri Toplama Araçları ve Analiz}

Araştırmada akademisyen memnuniyeti ölçmek için Mehmet Akif Ersoy Üniversitesi Akademik Değerlendirme ve Kalite Geliştirme Kurulu tarafından geliştirilen Akademik Personel Memnuniyet Ölçeği kullanılmıştır. Mehmet Akif Üniversitesi Akademik Personelinin Memnuniyet Anketi 2008 yllında Mehmet Akif Ersoy Üniversitesi'nin akademik personeline uygulanmış ve akademisyenlerin akademik-idari hizmetlerini değerlendirmesi, uzun-orta-kısa dönemli stratejik planlarını yapması, sunduğu hizmetin kalitesini sürekli geliştirmeyi amaçlamıştır. Ölçek beş alt boyuttan oluşmaktadır. Bu alt boyutlar yönetim ve örgütleme, eğitim, araştırma, alt yapı, paydaşlarla ilişkiler boyutlarıdır. Ölçek daha önce Mehmet Akif Ersoy Üniversitesi akademik personeline uygulanmış ve akademisyenlerin akademik-idari hizmetlerini değerlendirmesi, uzun-orta-kısa dönemli stratejik planlarını yapması, sunduğu hizmetin kalitesini sürekli geliştirmeyi amaçlamıştır. Ölçekte demografik özellikleri ölçmek için kişisel bilgi formu kullanılmıştır.

Güvenilirlik bilimsel araştırmaların şartlarındandır. Ölçüm sonuçları farklı olduğunda, güvenilir olan, doğru olan sonuç belirlenemez, diğer araştırmacılar da sonuçları anlatmakta güçlük çekerler ve sonuçları test edemezler. Güvenilirliğin düşük olması, yapılan çalışmanın değersiz olduğunu, elde edilen sonuçların anlamsız olduğunu ifade eder. Güvenilirlik göstergesi olarak güvenilirlik katsayısı

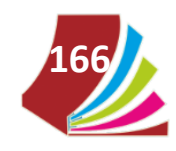


hesaplanır. Hesaplanan katsayı 0 ile 1 arasında değer alır. Bu katsayılardan en önemlisi Cronbach $\alpha$ katsayısıdır (Güriş, Astar, 2015,s.282-283).

Söz ettiğimiz gibi 0-1 arasında değer alan katsayı ile; $0 \leq \alpha \leq 0,5$ ise güvenilir değill, $0,5 \leq \alpha \leq$ 0,6 ise düşük güvenilir, $0,6 \leq \alpha \leq 0,7$ ise kabul edilebilir derece güvenilir, $0,7 \leq \alpha \leq 0,9$ ise iyi derecede güvenilir, $\alpha>0,9$ ise çok iyi derecede güvenilir, şeklinde ölçeğin güvenilirliği yorumlanır (Güriş, Astar, 2015, s.283).

Tablo 1'de ölçeğe ilişkin Cronbach's Alpha değerleri verilmiştir. Tablo 1'e göre; Akademik Personel Memnuniyet Ölçeğinin Cronbach’s Alpha güvenirlik katsayısı 0,955 çıkmıştır. Bu sonuç ölçeğin çok iyi derecede güvenilir olduğunu göstermektedir. Benzer şekilde ölçeğin alt boyutları olan yönetim ve örgütleme alt boyutunun Cronbach's Alpha güvenirlik katsayıs1 0,864, eğitim alt boyutunun Cronbach's Alpha güvenirlik katsayısı 0,838, araştırma alt boyutunun Cronbach's Alpha güvenirlik katsay1s1 0,930, alt yap1 alt boyutunun Cronbach's Alpha güvenirlik katsayıs1 0,861 ve paydaşlarla ilişkiler alt boyutunun Cronbach's Alpha güvenirlik katsayısı 0,832 çıkmıstır. Bu sonuçlar alt boyutlar açısından da ölçeğin iyi derecede güvenilir olduğunu göstermektedir.

\section{Tablo 1. Akademik Personel Memnuniyet Ölçeği Alt Boyutlarının Cronbach's Alpha Güvenilirlik Katsayısı}

\begin{tabular}{lc}
\hline $\begin{array}{l}\text { Akademik Personel Memnuniyet Ölçeği } \\
\text { Alt Boyutlar }\end{array}$ & $\begin{array}{c}\text { Cronbach's Alpha } \\
\text { Güvenirlik Katsayısı }\end{array}$ \\
\hline 1. Yönetim-Örgütleme & 0,864 \\
2. Ĕ̈itim & 0,838 \\
3.Araştırma & 0,930 \\
4.Altyap1 & 0,861 \\
5. Paydaşlarla İlişkiler & 0,832 \\
\hline Toplam & $\mathbf{0 , 9 5 5}$ \\
\hline
\end{tabular}

\section{Bulgular}

Araştırmanın bu kısmında araştırmaya dahil olan akademisyenlerin yanıtladıkları akademik personel memnuniyet ölçeğinden elde edilen bulgulara yer verilmiştir. Bu çerçevede öncelikle ölçeğin toplam ve her bir alt boyutuna (yönetim ve örgütleme, eğitim, araştırma, altyapı ve paydaşlarla ilişkiler) dair elde edilen ortalama ve standart sapma değerleri aktarılmıştır. Daha sonra ise araştırmaya ilişkin bulgular demografik özelliklere ilişkin bulgular ve fonksiyonel değişkenlere ilişkin bulgular olmak üzere iki başlik altında incelenerek tablolar halinde verilmiştir.

Tablo 2. Akademik Personel Memnuniyet Anketinin Toplam ve Alt Boyutlarna Ait Örneklem Sayısı, Aritmetik Ortalama ile Standart Sapma Değerleri

\begin{tabular}{lccc}
\hline $\begin{array}{l}\text { Ak. Per. Memnuniyet Ölçeği Alt } \\
\text { Boyutlar }\end{array}$ & N & $\overline{\mathbf{x}}$ & SS \\
\hline Yönetim-Örgütleme & 194 & 3,32 &, 68 \\
Ĕ̆itim & 194 & 3,14 &, 54 \\
\hline
\end{tabular}




\begin{tabular}{llll}
\hline Araştırma & 194 & 2,68 &, 58 \\
Altyap1 & 194 & 3,47 &, 56 \\
Paydaşlarla İlişkiler & 194 & 3,27 &, 95 \\
\hline Toplam & $\mathbf{1 9 4}$ & $\mathbf{3 , 1 7}$ & $\mathbf{, 4 7}$ \\
\hline
\end{tabular}

Tablo 2'de Akademik Personel Memnuniyet Anketi alt boyutlanndan elde edilen puanlara ilişkin veri sayısı $(\mathrm{N})$, aritmetik ortalama $(\mathrm{x})$ ve standart sapma (ss) değerleri verilmiştir. Bu sonuçlara göre akademisyenlerin en fazla olumlu görüş ortaya koydukları alt boyutun altyapı olduğu görülmüşken $(\bar{x}=3,47)$ bunu yönetim-örgütleme $(\bar{x}=3,32)$, paydaşlarla ilişkiler $(\bar{x}=3,27)$ ve eğitim $(\bar{x}=3,14)$ takip etmiştir. Akademisyenlerin en olumsuz görüş ortaya koydukları alt boyutun ise araştırma olduğu $(\bar{x}=2,68)$ olduğu görülmüştür. Akademisyenlerin memnuniyet anketinin toplamına dair verdikleri cevapların ortalaması ise $(\overline{\mathrm{x}}=3,17)$ olarak hesaplanmıştır.

\section{a. Demografik Özellikler (Tanımlayıcı İstatistikler)}

Bu kısımda demografik değişkenlere ilişkin frekans ve yüzdelik dağılımları verilmiştir.

Tablo 3. Demografik Değişkenlere İlişkin Frekans ve Yüzdelikler

\begin{tabular}{llcc}
\hline Demografik Değişkenler & & N & $\%$ \\
\hline \multirow{2}{*}{ Cinsiyet } & Kadın & 53 & 27 \\
& Erkek & 141 & 73 \\
\hline \multirow{3}{*}{ Yaş } & 25-29 Yaş & 21 & 11 \\
& 30-34 Yaş & 90 & 46 \\
& 35-39 Yaş & 64 & 33 \\
& 40-44 Yaş & 19 & 10 \\
\hline \multirow{3}{*}{ Unvan } & Prof. Dr. & 12 & 6 \\
& Doç. Dr. & 33 & 17 \\
& Dr. Öğr. Üy. & 47 & 24 \\
& Öğr. Gör. & 69 & 36 \\
Toplam Hizmet Süresi & Araş. Gör. & 33 & 17 \\
& 0-4 Y1l & 60 & 31 \\
& 5-9 Yıl & 63 & 33 \\
& 10-14 Yıl & 52 & 26 \\
& 15 Yıl ve üzeri & 19 & 10 \\
\hline
\end{tabular}

Tablo 3' ye göre; araştırmaya katılan akademik personelin 53'ünün (\%27) kadın, 141'inin (\%73) erkek, 21 'inin (\%11) 25-29 yaş aralığında, 90’ının (\%46) 30-34 yaş aralığında, 64'ünün (\%33) 35-39 yaş 
aralığında, 19’unun (\%10) 40-44 yaş aralığında olduğu görülmektedir. Tabloya göre araştırmaya katılan akademik personelin 12'sinin (\%6) profesör unvanına, 33’ünün (\%17) doçent unvanına, 47’sinin (\%24) doktor öğretim üyesi unvanına, 69’unun (\%36) öğretim görevlisi unvanına, 33’ünün (\%17) araştırma görevlisi unvanına sahip oldukları anlaşılmıştır. Tabloya göre araştırmaya katılan akademik personelin 60'ının (\%31) 0-4 y1l, 63’ünün (\%33) 5-9 y1l, 52'sinin (\%26) 10-14 y1l, 19’unun (\%10) 15 y1l ve üzeri toplam hizmet süresine sahip oldukları görülmektedir.

\section{b. Fonksiyonel Değişkenler}

Araştırmanın bu kısmında cinsiyet, unvan, yaş, hizmet süresi gibi fonksiyonel değişkenlere göre yapılan Mann Whitney U Testi ve Kruskal Wallis H Testlerine ilişkin analiz sonuçlanna yer verilmiştir.

\section{Tablo 4. Akademik Personel Memnuniyet Anketi’nin Cinsiyet Değişkenine Göre Mann-} Whitney $U$ Testi Sonuçlant

\begin{tabular}{|c|c|c|c|c|c|c|}
\hline $\begin{array}{c}\text { Ak. } \\
\text { Per.Memnuniyet } \\
\text { Ölçeği Alt } \\
\text { Boyutları }\end{array}$ & Cinsiyet & $\mathbf{N}$ & Sira Ort. & Sira Top. & $\mathbf{U}$ & $\mathbf{P}$ \\
\hline \multirow{2}{*}{ Yönetim-Örgütleme } & Erkek & 53 & 97,30 & 5157,00 & \multirow{2}{*}{3726,000} & \multirow{2}{*}{,976 } \\
\hline & Kadın & 141 & 97,57 & 13758,00 & & \\
\hline \multirow{2}{*}{ Eğitim } & Erkek & 53 & 92,02 & 4877,00 & \multirow{2}{*}{3446,000} & \multirow{2}{*}{,403 } \\
\hline & Kadın & 141 & 99,56 & 14038,00 & & \\
\hline \multirow{2}{*}{ Araştırma } & Erkek & 53 & 119,26 & 6321,00 & \multirow{2}{*}{2583,000} & \multirow{2}{*}{, $001 *$} \\
\hline & Kadın & 141 & 89,32 & 12594,00 & & \\
\hline \multirow{2}{*}{ Altyap1 } & Erkek & 53 & 90,96 & 4821,00 & \multirow{2}{*}{3390,000} & \multirow{2}{*}{,319 } \\
\hline & Kadın & 141 & 99,96 & 14094,00 & & \\
\hline \multirow{2}{*}{ Paydaşlarla İlişkiler } & Erkek & 53 & 94,74 & 5021,00 & \multirow{2}{*}{3590,000} & \multirow{2}{*}{,668 } \\
\hline & Kadin & 141 & 98,54 & 13894,00 & & \\
\hline
\end{tabular}

$*_{\mathrm{p}}<0,05$

Tablo 4 incelendiğinde araştırmaya katılan akademik personel memnuniyet ölçeği alt boyutlarından yönetim-örgütleme boyutunun ( $\mathrm{U}=3726,000 ; \mathrm{p}=0,976>0.05)$, eğitim boyutunun $(U=3446,000 ; p=0,403>0.05)$, altyap boyutunun $(U=3390,000 ; p=0,319>0.05)$ ve paydaşlarla ilişkiler boyutunun ( $\mathrm{U}=3590,000 ; \mathrm{p}=0,668>0.05)$ cinsiyet değişkenine göre anlamlı düzeyde farklılaşmadığ1 belirlenmiştir. Araştırma alt boyutunun $(U=3390,000 ; p=0,001<0.05)$ ise cinsiyet değişkenine göre anlamlı düzeyde farklılaştığı tespit edilmiştir. Sıra ortalamalara bakıldığında anlamlı farkın erkek personellerden kaynaklandığı görülmüştür. Erkek akademisyenlerin kadın akademisyenlere göre üniversitenin araştırma ile ilgili faaliyetlerinden daha memnun olduklarını söylemek mümkündür. 
Tablo 5. Akademik Personel Memnuniyet Anketi’nin Yaş Değişkenine Göre Kruskal Wallis H Test sonuçları

\begin{tabular}{|c|c|c|c|c|c|c|c|c|}
\hline $\begin{array}{c}\text { Ak. } \\
\text { Per.Memnuniyet } \\
\text { Ölçeği Alt } \\
\text { Boyutları }\end{array}$ & & Yaş & $\mathbf{N}$ & $\begin{array}{l}\text { Sira } \\
\text { Ort. }\end{array}$ & df & $\mathbf{X}^{2}$ & $\mathrm{p}$ & $\begin{array}{c}\text { Anlamli } \\
\text { Fark }\end{array}$ \\
\hline \multirow{4}{*}{ Yönetim-Örgütleme } & A & 25-29 Yaş & 21 & 88,67 & \multirow{4}{*}{3} & \multirow{4}{*}{11,641} & \multirow{4}{*}{, $009 *$} & \multirow{4}{*}{$\mathrm{C}>\mathrm{B}$} \\
\hline & $\mathrm{B}$ & 30-34 Yaş & 90 & 86,16 & & & & \\
\hline & $\mathrm{C}$ & 35-39 Yaş & 64 & 116,56 & & & & \\
\hline & $\mathrm{D}$ & 40-44 Yaş & 19 & 96,79 & & & & \\
\hline \multirow{4}{*}{ Eğitim } & $\mathrm{A}$ & 25-29 Yaş & 21 & 51,67 & \multirow{4}{*}{3} & \multirow{4}{*}{57,428} & \multirow{4}{*}{, $000 *$} & \multirow{4}{*}{$\mathrm{C}>\mathrm{A}$} \\
\hline & $\mathrm{B}$ & 30-34 Yaş & 90 & 83,94 & & & & \\
\hline & $\mathrm{C}$ & 35-39 Yaş & 64 & 138,70 & & & & \\
\hline & $\mathrm{D}$ & 40-44 Yaş & 19 & 73,61 & & & & \\
\hline \multirow{4}{*}{ Araştırma } & $\mathrm{A}$ & 25-29 Yaş & 21 & 96,33 & \multirow{4}{*}{3} & \multirow{4}{*}{10,295} & \multirow{4}{*}{, $016^{*}$} & \multirow{4}{*}{$\mathrm{C}>\mathrm{B}$} \\
\hline & $\mathrm{B}$ & 30-34 Yaş & 90 & 84,96 & & & & \\
\hline & $\mathrm{C}$ & 35-39 Yaş & 64 & 114,16 & & & & \\
\hline & $\mathrm{D}$ & 40-44 Yaş & 19 & 102,11 & & & & \\
\hline \multirow{4}{*}{ Altyap1 } & $\mathrm{A}$ & 25-29 Yaş & 21 & 34,33 & \multirow{4}{*}{3} & \multirow{4}{*}{30,501} & \multirow{4}{*}{, $000 *$} & \multirow{4}{*}{$\mathbf{D}>\mathbf{A}$} \\
\hline & $\mathrm{B}$ & 30-34 Yaş & 90 & 104,02 & & & & \\
\hline & $\mathrm{C}$ & 35-39 Yaş & 64 & 104,12 & & & & \\
\hline & $\mathrm{D}$ & 40-44 Yaş & 19 & 114,16 & & & & \\
\hline \multirow{4}{*}{ Paydaşlarla İlişkiler } & $\mathrm{A}$ & 25-29 Yaş & 21 & 96,33 & \multirow{4}{*}{3} & \multirow{4}{*}{0,115} & \multirow{4}{*}{,990 } & \\
\hline & $\mathrm{B}$ & 30-34 Yaş & 90 & 98,93 & & & & \\
\hline & $\mathrm{C}$ & 35-39 Yaş & 64 & 96,10 & & & & \\
\hline & $\mathrm{D}$ & 40-44 Yaş & 19 & 96,74 & & & & \\
\hline
\end{tabular}

${ }^{*} \mathrm{p}<0,05$

Tablo 5 incelendiğinde, araştırmaya katılan akademik personelin, yaşlarına göre akademik memnuniyet durumlarına bakıldığında, akademik personel memnuniyet ölçeği alt boyutlarından paydaşlarla ilişkiler boyutunun $\left[\mathrm{X}^{2}=0,115 ; \mathrm{p}=0,990>0.05\right]$ anlamlı düzeyde farklılaşmadı̆̆ı, yönetimörgütleme boyutunun $\left[X^{2}=11,641 ; p=0,009<0.05\right]$, eğitim boyutunun $\left[X^{2}=57,428 ; p=0,00<0.05\right]$, araştırma boyutunun $\left[\mathrm{X}^{2}=10,295 ; \mathrm{p}=0,016<0.05\right]$ ve altyap1 boyutunun $\left[\mathrm{X}^{2}=30,501 ; \mathrm{p}=0,000<0.05\right]$ ise anlamlı düzeyde farklılaştı̆̆ı belirlenmiştir.

Anlamlı farkın tespit edildiği gruplar arasındaki anlamlı farkın hangi gruplardan kaynaklandığını belirlemek için Mann Whitney U-testi yapılmıştır. Test sonuçlarına göre; 35-39 yaş aralığında bulunan 
akademik personelin, 30-34 yaş aralığındaki personele göre yönetim-örgütleme ve araştırma boyutundan daha memnun oldukları anlaşılmıştır. Yine benzer şekilde 35-39 yaş aralığındaki akademik personelin, 25-29 yaş aralığındaki personellere göre eğitim boyutundan daha memnun oldukları tespit edilmiştir. Ayrıca 40-44 yaş aralığında bulunan akademik personelin, 25-29 yaş aralığındaki personellere göre altyapı boyutundan daha memnun oldukları görülmektedir.

Tablo 6. Akademik Personel Memnuniyet Anketi’nin Unvan Değişkenine Göre Kruskal Wallis H Test sonuçları

\begin{tabular}{|c|c|c|c|c|c|c|c|c|}
\hline $\begin{array}{c}\text { Ak. Per. } \\
\text { Memnuniyet } \\
\text { Ölçeği Alt } \\
\text { Boyutları }\end{array}$ & & Unvan & $\mathbf{N}$ & Sira Ort. & df & $\mathbf{X}^{2}$ & $\mathrm{p}$ & $\begin{array}{c}\text { Anlamli } \\
\text { Fark }\end{array}$ \\
\hline \multirow{5}{*}{$\begin{array}{l}\text { Yönetim- } \\
\text { Örgütleme }\end{array}$} & $\mathrm{A}$ & Prof.Dr. & 12 & 121,83 & \multirow{5}{*}{4} & \multirow{5}{*}{5,120} & \multirow{5}{*}{,275 } & \\
\hline & B & Doç.Dr. & 33 & 93,30 & & & & \\
\hline & $\mathrm{C}$ & Dr.Öğ. Üye & 47 & 93,53 & & & & \\
\hline & $\mathrm{D}$ & Öğr. Gör. & 69 & 103,80 & & & & \\
\hline & $\mathrm{E}$ & Ar. Gör. & 33 & 85,33 & & & & \\
\hline \multirow{5}{*}{ Eğitim } & A & Prof.Dr. & 12 & 135,17 & \multirow{5}{*}{4} & \multirow{5}{*}{6,188} & \multirow{5}{*}{, 186 } & \\
\hline & B & Doç.Dr. & 33 & 94,62 & & & & \\
\hline & $\mathrm{C}$ & Dr.Öğ.Üye & 47 & 97,69 & & & & \\
\hline & $\mathrm{D}$ & Öğrr. Gör. & 69 & 95,84 & & & & \\
\hline & $\mathrm{E}$ & Ar. Gör. & 33 & 89,88 & & & & \\
\hline \multirow{5}{*}{ Araşturma } & $\mathrm{A}$ & Prof.Dr. & 12 & 135,00 & \multirow{5}{*}{4} & \multirow{5}{*}{16,970} & \multirow{5}{*}{, $002 *$} & \multirow{5}{*}{$\mathbf{A}>\mathbf{B}$} \\
\hline & $\mathrm{B}$ & Doç.Dr. & 33 & 71,30 & & & & \\
\hline & $\mathrm{C}$ & Dr.Öğ.ய̈ye & 47 & 107,66 & & & & \\
\hline & $\mathrm{D}$ & Öğrr. Gör. & 69 & 103,35 & & & & \\
\hline & $\mathrm{E}$ & Ar. Gör. & 33 & 83,36 & & & & \\
\hline \multirow{5}{*}{ Altyap1 } & $\mathrm{A}$ & Prof.Dr. & 12 & 139,67 & \multirow{5}{*}{4} & \multirow{5}{*}{31,766} & \multirow{5}{*}{, $000 *$} & \multirow{5}{*}{$\mathbf{A}>\mathbf{E}$} \\
\hline & $\mathrm{B}$ & Doç.Dr. & 33 & 72,95 & & & & \\
\hline & $\mathrm{C}$ & Dr.Öğ.Üye & 47 & 118,77 & & & & \\
\hline & $\mathrm{D}$ & Öğr. Gör. & 69 & 103,01 & & & & \\
\hline & $\mathrm{E}$ & Ar. Gör. & 33 & 64,89 & & & & \\
\hline \multirow{3}{*}{$\begin{array}{l}\text { Paydaşlarla } \\
\text { İlişkiler }\end{array}$} & A & Prof.Dr. & 12 & 124,25 & \multirow{3}{*}{4} & \multirow{3}{*}{17,699} & \multirow{3}{*}{, $001 *$} & \multirow{3}{*}{$\mathbf{A}>\mathbf{E}$} \\
\hline & B & Doç.Dr. & 33 & 86,71 & & & & \\
\hline & $\mathrm{C}$ & Dr.Öğ.Üye & 47 & 97,12 & & & & \\
\hline
\end{tabular}




$$
\begin{array}{llll}
\text { D } & \text { Öğr. Gör. } & 69 & 111,90 \\
\text { E } & \text { Ar. Gör. } & 33 & 69,00
\end{array}
$$

$*_{\mathrm{p}}<0,05$

Tablo 6 incelendiğinde, araştırmaya katılan akademik personelin, unvanlarına göre akademik memnuniyet durumlarına bakıldığında, akademik personel memnuniyet ölçeği alt boyutlarından yönetim-örgütleme boyutunun $\left[\mathrm{X}^{2}=5,120 ; \mathrm{p}=0,275>0.05\right]$ ve eğitim boyutunun $\left[\mathrm{X}^{2}=6,188\right.$; $\mathrm{p}=0,186>0.05]$ anlamlı düzeyde farklılaşmadığ1 tespit edilmiştir. Araştırma boyutunun $\left[\mathrm{X}^{2}=16,970\right.$; $\mathrm{p}=0,002<0.05]$, altyap 1 boyutunun $\left[\mathrm{X}^{2}=31,766 ; \mathrm{p}=0,000<0.05\right]$ ve paydaşlarla ilişkiler boyutunun $\left[\mathrm{X}^{2}=17,699 ; \mathrm{p}=0,001<0.05\right]$ ise anlamlı düzeyde farklılaştı̆̆ belirlenmiştir.

Anlamlı farklılı̆̆ın tespit edildiği gruplar arasındaki anlamlı farkın hangi gruplardan kaynaklandığını belirlemek için Mann Whitney U-testi yapılmıştır. Test sonuçlarına göre; profesör unvanına sahip akademik personelin, doçent unvanına sahip personele göre araştırma boyutundan daha memnun oldukları anlaşılmıştır. Yine benzer şekilde profesör unvanına sahip akademik personelin, araştırma görevlisi unvanına sahip personellere göre altyapı ve paydaşlarla ilişkiler boyutundan daha memnun oldukları tespit edilmiştir.

Tablo 7. Akademik Personel Memnuniyet Anketi’nin Toplam Hizmet Yılı Değişkenine Göre

\begin{tabular}{|c|c|c|c|c|c|c|c|c|}
\hline $\begin{array}{c}\text { Ak. Per. } \\
\text { Memnuniyet } \\
\text { Ölçeği Alt } \\
\text { Boyutları }\end{array}$ & & $\begin{array}{c}\text { Toplam } \\
\text { Hizmet } \\
\text { Y1li }\end{array}$ & $\mathbf{N}$ & Sira Ort. & df & $\mathbf{X}^{2}$ & $\mathrm{p}$ & $\begin{array}{c}\text { Anlamli } \\
\text { Fark }\end{array}$ \\
\hline \multirow{4}{*}{$\begin{array}{l}\text { Yönetim- } \\
\text { Örgütleme }\end{array}$} & A & 0-4 Y1l & 87 & 97,45 & \multirow{4}{*}{3} & \multirow{4}{*}{3,520} & \multirow{4}{*}{,318 } & \\
\hline & B & 5-9 Y1l & 69 & 94,54 & & & & \\
\hline & $\mathrm{C}$ & 10-14 Y1l & 26 & 92,38 & & & & \\
\hline & $\mathrm{D}$ & $\begin{array}{l}15 \text { Y1l ve } \\
\text { üzeri }\end{array}$ & 12 & 126,00 & & & & \\
\hline \multirow{4}{*}{ Eğitim } & $\mathrm{A}$ & 0-4 Yil & 87 & 87,67 & \multirow{4}{*}{3} & \multirow{4}{*}{6,130} & \multirow{4}{*}{, 105 } & \\
\hline & B & 5-9 Y1l & 69 & 110,00 & & & & \\
\hline & $\mathrm{C}$ & 10-14 Yil & 26 & 97,92 & & & & \\
\hline & $\mathrm{D}$ & $\begin{array}{l}15 \text { Yil ve } \\
\text { üzeri }\end{array}$ & 12 & 96,00 & & & & \\
\hline \multirow{4}{*}{ Araşturma } & $\mathrm{A}$ & $0-4 Y_{1} l$ & 87 & 102,30 & \multirow{4}{*}{3} & \multirow{4}{*}{5,864} & \multirow{4}{*}{,118 } & \\
\hline & B & 5-9 Yil & 69 & 95,78 & & & & \\
\hline & $\mathrm{C}$ & 10-14 Yil & 26 & 76,65 & & & & \\
\hline & $\mathrm{D}$ & $\begin{array}{l}15 \text { Yil ve } \\
\text { üzeri }\end{array}$ & 12 & 117,75 & & & & \\
\hline
\end{tabular}
Kruskal Wallis H Test sonuçları 


\begin{tabular}{|c|c|c|c|c|c|c|c|c|}
\hline \multirow{4}{*}{ Altyap1 } & $A$ & $0-4 Y_{11}$ & 87 & 96,02 & \multirow{4}{*}{3} & \multirow{4}{*}{17,869} & \multirow{4}{*}{, $000^{*}$} & \multirow{4}{*}{ D $>$ B } \\
\hline & B & 5-9 Y1l & 69 & 82,71 & & & & \\
\hline & C & 10-14 Y1l & 26 & 119,21 & & & & \\
\hline & $\mathrm{D}$ & $\begin{array}{l}15 \text { Y1l ve } \\
\text { üzeri }\end{array}$ & 12 & 146,25 & & & & \\
\hline \multirow{4}{*}{$\begin{array}{l}\text { Paydaşlarla } \\
\text { İlişkiler }\end{array}$} & A & $0-4 Y_{11}$ & 87 & 108,96 & \multirow{4}{*}{3} & \multirow{4}{*}{10,532} & \multirow{4}{*}{, $015^{*}$} & \multirow{4}{*}{$A>B$} \\
\hline & B & 5-9 Y1l & 69 & 81,09 & & & & \\
\hline & $\mathrm{C}$ & 10-14 Y 1 & 26 & 105,13 & & & & \\
\hline & $\mathrm{D}$ & $\begin{array}{l}15 \text { Yil ve } \\
\text { üzeri }\end{array}$ & 12 & 92,25 & & & & \\
\hline
\end{tabular}

$*_{\mathrm{p}}<0,05$

Tablo 7 incelendiğinde, araştırmaya katılan akademik personelin, toplam hizmet yıllarına göre akademik memnuniyet durumlarına bakıldığında, akademik personel memnuniyet ölçeği alt boyutlarından yönetim-örgütleme boyutunun $\left[\mathrm{X}^{2}=3,520 ; \mathrm{p}=0,318>0.05\right]$, eğitim boyutunun $\left[\mathrm{X}^{2}=6,130 ; \mathrm{p}=0,105>0.05\right]$ ve araşturma boyutunun $\left[\mathrm{X}^{2}=5,864 ; \mathrm{p}=0,118>0.05\right]$ anlaml düzeyde farklılaşmadığ 1 tespit edilmiştir. Altyapı boyutunun $\left[\mathrm{X}^{2}=17,869 ; \mathrm{p}=0,000<0.05\right]$ ve paydaşlarla ilişkiler boyutunun $\left[\mathrm{X}^{2}=10,532 ; \mathrm{p}=0,015<0.05\right]$ ise anlamlı düzeyde farklılaştığı belirlenmiştir.

Anlamlı farklılı̆̆ın tespit edildiği gruplar arasındaki anlamlı farkın hangi gruplardan kaynaklandığını belirlemek için Mann Whitney U-testi yapılmıştır. Test sonuçlarına göre; 15 yıl ve üzeri toplam hizmet süresine sahip akademik personelin, 5-9 yıl hizmet süresine sahip personele göre altyap1 boyutundan daha memnun oldukları anlaşılmıştır. Yine benzer şekilde 0-4 yıl toplam hizmet süresine sahip akademik personelin, 5-9 y1l toplam hizmet süresine sahip personellere göre paydaşlarla ilişkiler boyutundan daha memnun oldukları tespit edilmiştir.

\section{Sonuç ve Öneriler}

Araştırmada, üniversitede çalışan akademisyenlerin yönetim ve örgütleme, eğitim, araştırma, altyap1 ve paydaşlarla ilişkilerdeki memnuniyet düzeylerinin belirlenmesi amaçlanmış ve şu sonuçlara ulaşılmıştır. Araştırma bulguları incelendiğinde akademisyenlerin en fazla olumlu görüş ortaya koydukları alt boyutun altyap1 olduğu görülmüşken $\left(\bar{x}^{-}=3,47\right)$ bunu yönetim-örgütleme $(\bar{x}=3,32)$, paydaşlarla ilişkiler $(\bar{x}=3,27)$ ve eğitim $(\bar{x}=3,14)$ takip etmiştir. Akademisyenlerin en olumsuz görüş ortaya koydukları alt boyutun ise araştırma olduğu $(\bar{x}=2,68)$ olduğu görülmüştür. Bunun nedeninin yeni kurulan üniversitelerde öğretim elemanı yetersizliği nedeniyle ders yükünün fazla olmasından kaynaklı ögretim elemanlarının akademik araştırma yapmaya fazla zaman bulamamaları söylenebilir. Ayrıca öğretim elemanlarının çalıştıkları kurumlarım yeni kurulmuş olması nedeniyle akademik çalışmalarının nitelikli dergiler tarafından kabul edilmememsi de söylenebilir. Akademisyenlerin memnuniyet anketinin toplamına dair verdikleri cevapların ortalaması ise $(\bar{x}=3,17)$ olarak hesaplanmıştır. Bu sonuç, Baş (2002), Paksoy (2007), Kılıç ve Gümüşeli (2010), İncik ve Tanrısever (2012), Alparslan (2015), Turhan ve Erol (2017) ve Araç (2018) tarafindan yapılan araştırmaların sonuçları ile benzerlik göstermektedir. Araştırmaya katılan akademisyenlerin, üniversitenin yönetim ve örgütleme, eğitim, altyapı ve paydaşlarla ilişkiler alt boyutları açısından cinsiyet değişkenine göre

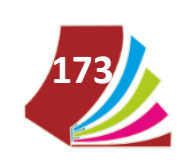


anlamlı farklılık göstermediği ancak araştırma alt boyutunda erkek akademisyenler lehine anlamlı farklılık gösterdiği sonucuna ulaşılmışır.

Araştırmaya katılan akademik personelin yaş değişkenine göre; ölçeği alt boyutlarından paydaşlarla ilişkiler boyutunun $(\mathrm{p}=0,990>0.05)$ anlamlı düzeyde farklılaşmadı̆̆1, yönetim-örgütleme boyutunun $(p=0,009<0.05)$, eğitim boyutunun $(p=0,00<0.05)$, araştırma boyutunun $(p=0,016<0.05)$ ve altyapı boyutunun $(\mathrm{p}=0,000<0.05)$ ise anlamlı düzeyde farklılaştı̆̆ belirlenmiştir. Test sonuçlarına göre; 35-39 yaş aralığında bulunan akademik personelin, 30-34 yaş aralığındaki personele göre yönetimörgütleme ve araştırma boyutundan daha memnun oldukları ve yine benzer şekilde 35-39 yaş aralığındaki akademik personelin, 25-29 yaş aralığındaki personellere göre eğitim boyutundan daha memnun oldukları tespit edilmiştir. Ayrıca 40-44 yaş aralığında bulunan akademik personelin, 25-29 yaş aralığındaki personellere göre altyapı boyutundan daha memnun oldukları görülmektedir. Bu durumuna profesör, docent ve doktor öğretim üyesi kadrolarındaki akademik personelin yaş olarak daha ileri yaşta olmaları ve üniversitenin yönetim kademelerinde yer alıyor olmaları neden olarak gösterilebilir.

Araştırmaya katılan akademik personelin, unvan değişkenine göre akademik memnuniyet durumlarına bakıldığında, akademik personel memnuniyet ölçeği alt boyutlarından yönetim-örgütleme boyutunun $(p=0,275>0.05)$ ve eğitim boyutunun $(p=0,186>0.05)$ anlamlı düzeyde farklılaşmadığ1 sonucuna ulaşılmıştır. Araştırma boyutunun $(p=0,002<0.05)$, altyap boyutunun $(p=0,000<0.05]$ ve paydaşlarla ilişkiler boyutunun $(\mathrm{p}=0,001<0.05)$ ise anlamlı düzeyde farklılaştığı belirlenmiştir. Profesör unvanına sahip akademik personelin, doçent unvanına sahip personele göre araştırma boyutundan daha çok memnun oldukları, yine benzer şekilde profesör unvanına sahip akademik personelin, araştırma görevlisi unvanına sahip personellere göre altyapı ve paydaşlarla ilişkiler boyutundan daha çok memnun oldukları tespit edilmiştir. Bu durumu da yine professor unvanında bulunan akademik personelin ağırlıklı olarak üniversite yönetiminde yer alması neden olarak gösterilebilir.

Araştırmaya katılan akademik personelin, toplam hizmet yıllarına göre akademik memnuniyet durumlarına bakildığında, yönetim-örgütleme boyutunun $(\mathrm{p}=0,318>0.05)$, eğitim boyutunun $(p=0,105>0.05)$ ve araştırma boyutunun $(p=0,118>0.05)$ anlamlı düzeyde farklılaşmadığ tespit edilmiştir. Altyapı boyutunun $(p=0,000<0.05)$ ve paydaşlarla ilişkiler boyutunun $(p=0,015<0.05)$ ise anlamlı düzeyde farklılaştı̆̆ görülmüştür. 15 yll ve üzeri toplam hizmet süresine sahip akademik personelin, 5-9 yıl hizmet süresine sahip personele göre altyapı boyutundan daha çok memnun oldukları görülmüştür. Yine benzer şekilde 0-4 yıl toplam hizmet süresine sahip akademik personelin, 5-9 y1l toplam hizmet süresine sahip personellere göre paydaşlarla ilişkiler boyutundan daha memnun oldukları tespit edilmiştir. Yaşanan memnuniyetsilikler üniversitenin yeni kurulmuş olması nedeniyle ekonomik, sosyal, kültürel olarak yaşadığı sorunlara bağlanabilir. Ayrıca üniversitenin bulunduğu coğrafik konum, kış mevsiminin uzun sürmesi ve uzak bir şehirde olması da yine yaşanan memnuniyetsizliklere neden olduğu düşünülmektedir.

Araştırma sonuçlarına göre aşağıdaki öneriler sıralanmıştır:

- $\quad$ Üniversitede araştırma faaliyetleri kapsamında akademisyenlere yurt içi ve yurt dişı bilimsel kongre ve toplantulara katulım için verilen maddi desteğin iyileştirilmesi sağlanabilir. Bununla birlikte akademisyenlerin yurt dışında da çalışma yapabilmelerinin kolaylaştırılması ve parasal destek verilmesi, bunun yanında nitelikli yayın yapılabilmesi için akademisyenlerin yöneticiler tarafindan motive edilmesi ve manevi olarak desteklemesi sağlanabilir.

- Eğitim olanaklarının fiziki şartlarının iyileştirilmesi sağlanarak sayılarının artırılması ve akademisyenlerin daha nitelikli eğitim verebilmeleri için eğitim ortamlarının düzenlenmesi sağlanabilir. 
- Paydaşlarla olan ilişkilerin artırılması için ilişkilerin yeniden gözden geçirilmesi sağlanarak iletişim kanalları genişletilebilir.

- Yönetim ve örgütleme olarak liyakat sahibi, yetkinliği olan personellerin yönetim kademelerine atanması ile akademisyenlerin yönetim ve örgütleme boyutunda memnuniyetleri artır1labilir. Ayrıca her bir birim veya kişi ile ilgili alınacak olan kararlara, birim ve kişilerin katılımı sağlanarak memnuniyetleri artırilabilir.

- Aynı konuyu çalışmak isteyen araştırmacılara, tek bir üniversite ile sınırlı kalmadan birkaç farklı üniversitenin karşılaştırmasını yapmaları önerilmektedir. 


\section{Kaynakça}

Acar, M. (2012). Üniversitelerde Yeniden Yapılanmanın Aciliyeti Ve Yeni Üniversitelerin Sorunlar1. Eğitime Bakış Dergisi, 8(23), 21-27.

Aktan, C. (2007). Yükesekögretimde Değtşim: Global Trendler Ve Yeni Paradigmalar. İzmir: Yaşar Üniversitesi Yayın.

Alparslan, A. M. (2015). Öğretim Elemanlarmm Isslerinden Tatmin, Üniversitelerinden Memnun Ve Gönüllü Olmalarndaki Öncüller: Mebmet Akif Ersoy Üniversitesi'nde Bir Araştırma-The Antecedent Of Job Satinsfaction, Satinsfaction From The University And Extra-Role Behavior: A Survey. Mehmet Akif Ersoy Üniversitesi Sosyal Bilimler Enstitüsü Dergisi, 6(11), 82-101.

Altunsoy, S. (2011). Yeni Devlet Üniversitelerinin Gelişimi: Sorunlar Ve Politika Önerileri. Yükseköğretim ve Bilim Dergisi, 1(2), 98- 104.

Araç, E. K., (2018). Öğretmen Adaylar Ve Akademisyenlerin Memnuniyet Düzeylerini Etkileyen Faktörler: Sinf Öğgretmenlĭ̆i Ana Bilim Dalının Sorunlarnnı İncelenmesi. Yayınlanmamış Yüksek Lisans Tezi.

Aydemir, M., \& Erşan, C. (2011). Yeni Kurulan Üniversitelerde Örgütsel Bağglilik Sorunu. Afyon Kocatepe Üniversitesi İktisadi ve İdari Bilimler Fakültesi Dergisi, 13(1), 55-72.

Baş, T. (2002). “Öğretim Üyelerinin İş Tatmin Profillerinin Belirlenmesi”, Dokuz Eylül Üniversitesi İ.I.B.F Dergisi, 17(2), 19-37.

Doğan, D. (2013). Yeni Kurulan Üniversitelerin Sorunlar ve Çözüm Önerileri. Journal of Higher Education \& Science/Yüksekögretim ve Bilim Dergisi, 3(2).

Eyüpoğlu, S. Z. ve Saner, T. (2009). The Relationship Between Job Satisfaction and Academic Rank: A Study of Academicians in Northern Cyprus", Paper presented at the World Conference on Educational Science, Northern Cyprus, 20th October, Business Administration Department: East University Lefkosa, 686691.

Günay D., \& Günay A. (2011). 1933'den Günümüze Türk Yüksekögretiminde Niceliksel Gelişmeler. Yükseköğretim ve Bilim Dergisi, 1(1), 1-22.

Güriş Selahattin, Astar Melek, SPSS İle İstatistik, 2015-DR Yayınc1lık, İstanbul.

Handy, C. B. (1981). Understanding organisations. Harmondsworth: Penguin. 
İncik, E. Y. ve Tanriseven, I. (2012). Eğitim Fakültesi Öğretim Elemanlarmmn Ve Öğretmen

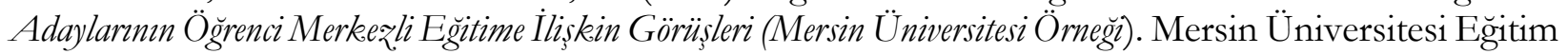
Fakültesi Dergisi, 8(3), 172-184.

Karagözoğlu, G. (2003). Eğitim Sistemimizde Ögretmen Yetiştirme Politikamıza Genel Bir Bakıs, Eğitimde Yansımalar. VII Çağdaş Eğitim Sistemlerinde Öğretmen Yetiştirme Sempozyumu, Cumhuriyet Üniversitesi Kültür Merkezi.

K1lı̧, S. Z. ve Gümüşeli, A. İ. (2010). "İstanbul ili vakıf üniversitelerine bağg meslek yü̈ksekokullarnnda görevli ögretim elemanlarnın iş doyum düzeyleri”, İstanbul Üniversitesi İşletme Fakültesi Dergisi, 39(2) 290309.

Machado Taylor, M. de L., Soares, V. M., Ferreira, J. B. and Gouveia, O. M. R. (2011). What Factors Of Satisfaction And Motivation Are Affecting The Development Of The Academic Career In Portuguese Higher Education Institution? RAP- Rio de Janeiro, 45(1), 33-44.

Marginson, S., \& Rhodes, G. (2002). Beyond National States, Markets, And Systems Of Higher Education. Higher Education,43, 281-309.

Noordin, F. and Jusoff, K. (2009). Levels of job satisfaction amongst Malaysian academic staff. Asian Social Science, 5(5), 122-128.

Ortaş, İ. (2002). Üniversitelerin Sorunlar I. Bilim, Eğitim ve Düşünce Dergisi, 2(4), 3.

Paksoy, H. M. (2007). "Üniversitelerde Akademik Personelin Iss Memnuniyeti: Harran Üniversitesi Örneği”, S.Ü. Karaman İktisadi ve İdari Bilimler Dergisi Fakültesi Dergisi, 12(9), 138-151.

Rebolloso-Pacheco. and Pozo-Muñ, C. (2000). "The Ideal Teacher'Implications For Student Evaluation Of Teacher Effectiveness", Assessment \& Evaluation in Higher Education, 25(3).

Şenses, F. (2007). Uluslararası Gelismeler Isı̆̈ında Türkiye Yüksekögretim Sistemi: Temel Eğilimler, Sorunlar, Çeliskiler Ve Öneriler (pp. 1-31). Economic Research Center, ODTÜ, Ankara.

Tanr1kulu, D. (2011). Türkiye'de Yüksekëğretime Erişim: 2025 Yllnda Yüksekëgrretim Talebi Karşılanabilecek Mi? (Analiz No. 34). Ankara: SETA.

TED (2011). Yüksekögrretimin Yeniden Yapılandırlması: Görüs Ve Öneriler. Ankara. 
Turhan, M. ve Erol, Y. C. (2017). Akademisyenlerin Akademik Teşvik Ödeneğine İlişkin Görüsleri. İnönü Üniversitesi Eğitim Fakültesi Dergisi, 18(3), 281-296. DOI: 10.17679/inuefd.341708.

$\underline{\text { www.agri.edu.tr }}$

https://istatistik.yok.gov.tr/ 